\title{
Effect of Rotavirus Infection and Malnutrition on Uptake of a Dietary Antigen in the Intestine ${ }^{1}$
}

\author{
INGRID S. UHNOO, ${ }^{2}$ JOACHIM FREIHORST, ${ }^{3}$ MARIE RIEPENHOFF-TALTY, \\ JOHN E. FISHER, AND PEARAY L. OGRA
}

\begin{abstract}
Departments of Pediatrics [M.R-T., P.L.O.] and Microbiology [I.S.U., J.F., M.R-T., P.L.O.] State University of New York at Buffalo, and Division of Infectious Diseases and Microbiology Laboratories [I.S.U., J.F., M.R-T., P.L.O.], and Department of Pathology [J.E.F.], The Children's Hospital, Buffalo, New York 14222
\end{abstract}

\begin{abstract}
Intestinal absorption of ovalbumin (OVA), a dietary macromolecule, was studied in malnourished and normally nourished suckling mice after experimentally induced infection with rotavirus. All mice developed diarrhea within 24 to $48 \mathrm{~h}$ postinoculation. The malnourished animals exhibited more severe symptoms and an increased number of rotavirus-containing enterocytes in intestinal sections as compared to well-nourished mice when examined $3 \mathrm{~d}$ postinoculation, at the peak of diarrhea. Histopathologic examination revealed villus atrophy and pronounced vacuolization of villus enterocytes in association with malnutrition and rotavirus infection. The combination of malnutrition and viral infection resulted in more severe mucosal damage, including disruption of microvillus borders. After a single oral dose of $100 \mu \mathrm{g}$ OVA at $3 \mathrm{~d}$ postinoculation, the concentration of OVA in serum, gastric content, intestinal lavage fluid, and intestinal tissue homogenates was measured at different time intervals. The concentrations of OVA in intestinal tissue were significantly higher in malnourished animals, whereas lower values were found in rotavirus-infected animals. In all mice, OVA was rapidly absorbed and could be consistently detected in the serum within $5 \mathrm{~min}$. OVA levels peaked at 45 to $60 \mathrm{~min}$ and then gradually declined. In malnourished infected animals, the uptake of OVA was rapid and resulted in significantly higher serum levels when compared to well nourished or uninfected controls, respectively. The peak uptake of OVA per $\mathrm{g}$ body wt was about 4.5 times more in malnourished infected compared to well-nourished infected mice and 2.5 times higher in normally nourished infected animals when compared to uninfected controls. These results indicate that rotavirus infection in association with malnutrition may cause a significant rise in gut permeability to environmental macromolecules. (Pediatr Res 27:153160, 1990)
\end{abstract}

\section{Abbreviations}

OVA, ovalbumin

pi, postinoculation

ID $_{50}, 50 \%$ infectious dose

IFA, immunofluorescence assay

Received May 18, 1989; accepted October 10, 1989.

Correspondence and reprint requests Dr. P.L. Ogra, Division of Infectious Diseases, Children's Hospital, 219 Bryant Street, Buffalo, NY 14222.

Supported in part by grants from the National Institute of Allergy and Infectious Diseases (AI-15939-10, AI-21033-03), the World Health Organization (WHO 2797), and the Swedish Medical Research Council.

${ }^{1}$ Presented in part at the Annual Meeting of the Society for Pediatric Research/ American Pediatric Society, Washington, DC, May 1-5, 1988.

2 Present address Department of Infectious Diseases, University Hospital, S-75185 Uppsala, Sweden.

${ }^{3}$ Present address Kinderklinik der Medizinischen Hochschule Hannover, Konstanty-Gutschow Str. 83000 Hannover 91, FRG.
The combination of malnutrition and diarrheal disease is the single most important cause of death in children less than $5 \mathrm{y}$ of age (1). Rotaviruses are the most common etiologic agents of viral enteritis in infants and young children with significant morbidity as well as mortality, particularly in less developed countries where malnutrition is highly prevalent $(2,3)$. Epidemiologic data have shown that acute enteric infections aggravate and potentiate nutritional deficiencies, whereas malnutrition increases the attack rate and the severity of diarrhea with prolonged duration of symptoms $(4,5)$. However, little is known about the interaction between environmental macromolecules and the intestinal epithelium during enteric infections in the malnourished host.

Rotavirus exclusively infects the terminally differentiated villus enterocytes in the small intestine $(6,7)$. The mucosal damage in human infants includes villus atrophy and necrosis of villus epithelial cells followed by a replacement with immature cells with altered absorptive capacities $(2,6)$. Severe malnutrition is known to cause small intestinal atrophy $(8,9)$ and altered intestinal mucosal defense $(10,11)$. Based on these observations, it has been suggested that the intestine during malnutrition and infection may become more permeable to macromolecules with increased passage of environmental antigenic materials into systemic circulation, resulting in potentially adverse effects $(12,13)$.

The purpose for this study was to examine the effect of malnutrition and rotavirus infection on intestinal barrier function. This was assessed by measuring concentration of OVA in serum after oral OVA administration as an indication of intestinal permeability. In addition, morphologic studies of the small intestine were performed to determine if structural differences existed to explain any alteration of intestinal transport noted. The rotavirus infection in the suckling mouse model, due to its similarity to the disease in human infants (14), provides an excellent system in which to examine these mechanisms. Our results indicate that in mice both rotavirus infection and, in particular, malnutrition cause an increased uptake of macromolecules.

\section{MATERIALS AND METHODS}

Animals. BALB/c mice were purchased from rotavirus-free colonies from Charles River Breeding Laboratories, Inc., Portage, MI. All animals were shipped in isolator cages and transferred to microisolator cages on arrival at Children's Hospital. The animals were raised on OA-free food (Mouse Breeder Diet, Teklad Harlan Sprague Dawley, Inc. Co., Winfield, IA). Infant mice were allowed to suckle throughout the period of experimentation. After inoculation, rotavirus-infected animals were kept in separate facilities from uninfected control animals.

Induction and assessment of malnutrition. Acute protein-cal-

orie malnutrition was achieved by expanding the litter size to 
three times the normal size, thereby substantially reducing total nutrient intake. This system originally developed in rats (15) has previously been used in our laboratory in related studies of infection and malnutrition (16). The newborn mice were distributed within 12 to $24 \mathrm{~h}$ after birth to adoptive mothers so that litters were expanded to 18 to 20 pups for experimental malnourished groups and to seven to nine pups for normal controls. Body wt of the suckling mice and wt and lengths of small intestine were recorded at $9 \mathrm{~d}$ of age. Quantitative measurement of serum albumin by the Bromcresol Green Albumin Reagent test (Worthington Diagnostics Systems, Inc., Freehold, NJ) was carried out on pooled sera from groups of two to four malnourished and normally nourished mice. Whole blood was also collected for measurement of hematocrit.

Virus. Mouse rotavirus strain epizootic diarrhea of infant mice 5099 , kindly supplied by Dr. R. Wyatt of the National Institutes of Health, Bethesda, MD, was passed 14 times in suckling mice. The virus-rich intestinal homogenate was clarified by low-speed centrifugation and used as an inoculum. ID $_{50}$ end-point of the virus pool was calculated according to the Reed-Muench method (17). Groups of 10 litters of suckling mice were fed with serial dilutions of virus in a constant volume of $5 \mu \mathrm{L}$. The $\mathrm{ID}_{50}$ was calculated as the dose of virus that produced moderate diarrhea in $50 \%$ of the animals of a litter $72 \mathrm{~h}$ after virus inoculation. The titer of the preparation used in these experiments was $2 \times 10^{7}$ $\mathrm{ID}_{s 0} / \mathrm{mL}$.

Antigen. OVA, grade V (Sigma Chemical Co., St. Louis, MO) was dissolved at a concentration of $10 \mathrm{mg} / \mathrm{mL}$ in sterile PBS.

Experimental protocol. Groups of malnourished and well nourished animals were fed $7 \mu \mathrm{L}$ of a $10^{-3}$ dilution of the rotavirus preparation $\left(1.4 \times 10^{2} \mathrm{ID}_{50}\right)$ at $6 \mathrm{~d}$ of age using a micropipetter with a small disposable tip. Sufficient time and suckling was allowed for the infant mouse to swallow the liquid. The infected animals were inspected daily for fecal staining and assessed for diarrhea after gentle palpation of the abdomen. Then $3 \mathrm{~d} \mathrm{pi}$ at the peak of diarrhea, the animals were given a single dose of $10 \mu \mathrm{g}(100 \mu \mathrm{g})$ of OVA orally by a micropipetter or intragastrically by a feeding needle. Groups of five to 12 animals were killed at different time intervals from $5 \mathrm{~min}$ to $12 \mathrm{~h}$ after OVA administration. Additional mice were used for viral antigen detection by immunofluorescence assay, histopathology, and ultrastructural studies. Controls were age-matched uninfected malnourished and well-nourished animals.

Specimen collection and processing. Blood samples were collected by intracardiac puncture. Serum was stored at $-20^{\circ}$. Intestinal segments from proximal duodenum to distal ileum were removed, weighed, and flushed three times with $2 \mathrm{~mL}$ of sterile PBS per g tissue. The weighed segments of intestine were then homogenized in PBS in a tissue grinder (Thomas Scientific, Swedesboro, NJ). The stomach was homogenized in a similar manner. The homogenates and intestinal washings were clarified by low-speed centrifugation and stored at $-20^{\circ} \mathrm{C}$ until tested for OVA antigen by ELISA.

In other experiments, segments from duodenum, jejunum, and ileum were collected immediately after blood collection. The tissues were embedded in OCT compound (Tissue-Tek, Miles Inc., Elkhart, IN) and frozen in isopentane/liquid nitrogen and stored at $-70^{\circ} \mathrm{C}$ until use. Five- $\mu$ thick sections were cut manually using a Cyrocut Microtome (American Optical Corp., Buffalo, $\mathrm{NY}$ ) then placed on gelatin-coated slides and air dried. The slides were stored at $-20^{\circ} \mathrm{C}$ until used for immunofluorescent staining. Adjacent sections of the small intestine were fixed in $3 \%$ glutaraldehyde (EMS, Fort Washington, PA), processed and stained with uranyl acetate and lead citrate for ultrastructural studies by electron microscopy. Additional sections of duodenum, jejunum, and ileum were fixed in buffered $10 \%$ formalin solution (Lyne Laboratories, Stroughton, MA), embedded in paraffin and stained with hematoxylin and eosin for histopathology.

ELISA. OVA concentration in several samples of serum, intestinal lavage fluid, and gastric and intestinal tissue homogenates was determined by a sandwich-type ELISA (18). Rabbit
anti-OVA antiserum (IgG fraction) was coated to poly-vinyl microtitration plates (Dynatech Lab, Inc., Chantilly, VA) and peroxidase-conjugated rabbit anti-OVA antiserum (IgG fraction) was used for detection (both Cooper Biomedical, Malvern, PA). The absorbance values of test samples were obtained by diluting a standard solution containing $100 \mathrm{ng}$ of OVA dissolved in normal mouse serum. Results were expressed as multiples of the standard solutions. Test samples from corresponding groups of animals uninfected and infected were run on the same microtiter plate.

Selected fecal samples from all four animal groups were collected in $0.5 \mathrm{~mL}$ PBS, and a commercially available ELISA using a MAb (Kallestad Laboratories, Austin, TX) was used for detection of rotavirus.

$I F A$. Cryostat tissue sections were fixed in cold acetone for 10 min. After rehydration in PBS, the sections were incubated with hyperimmune guinea pig anti-murine rotavirus serum for 30 min (19). After washing three times in PBS, the slides were incubated with fluorescein-conjugated goat anti-guinea pig IgG (Accurate Chemical and Scientific Co., Westbury, NJ). The slides were then washed, air-dried, counterstained with Evans blue (Sigma Diagnostics, St. Louis, MO) and covered with a coverslip and PBS-glycerol. The specificity of the IFA was controlled by appropriate blocking experiments using gnotobiotic pig-antirotavirus serum (kindly provided by Dr. L. Saif, Ohio State University, Wooster, $\mathrm{OH}$ ) incubated on the slide before staining with IFA reagents. The slides were examined using a $\mathrm{BH}-2$ Olympus fluorescent microscope.

Statistical analysis. OVA concentrations in test samples were calculated as the arithmetic mean \pm SEM for each time point and each experimental group and assessed for significance of differences by paired $t$ test. To test the main effect of time and independent group differences, two-way ANOVA multivariate analysis was used.

\section{RESULTS}

Effect of litter expansion on nutrition and viral infection. When suckling mice, 12 to $16 \mathrm{~h}$ old, were distributed and maintained in litters of 17 to 20 pups with a single mother, they were severely protein-calorie malnourished by $9 \mathrm{~d}$ of age. As shown in Table 1 , mice in the expanded litters achieved only $60 \%$ of the wt compared to those in a normal litter. The mean intestinal wt were significantly less $(p<0.001)$ in malnourished compared to normally nourished controls. The mean length of small intestine also differed significantly, with a mean of $13.4 \mathrm{~cm}$ in malnourished mice (15 animals) as compared with $17.4 \mathrm{~cm}$ in control mice (20 animals) $(p<0.001)$. Serum albumin levels were reduced $24 \%$ in mice from expanded litters. There were no significant differences in hematocrit values among experimental groups and controls.

All rotavirus infected animals exhibited diarrhea 24 to $48 \mathrm{~h}$ after inoculation. Malnourished mice had more severe symptoms with an increased number of watery yellow stools and more pronounced fecal staining than controls. Similar to the findings in uninfected animals, the body wt and intestinal wt were significantly lower in infected malnourished mice compared to normally nourished infected mice. The representative data of wt recorded at $3 \mathrm{~d}$ pi (at the peak of diarrhea) are presented in Table 1. Random sampling of stools from infected mice were all positive for rotavirus antigen by ELISA, whereas fecal specimens from uninfected animals remained negative.

In infected animals villus enterocytes in all parts of the intestinal tract were positive for rotavirus antigen. The highest number of virus-positive cells were found in the ileum. Virus antigen was present in the cytoplasm of epithelial cells on the upper twothirds of intestinal villi with no evidence of infection in the lower third or in the crypts. In malnourished animals the staining for rotavirus antigen was more intense and abundant as compared to normally nourished animals (Fig. $1 A$ and $B$ ). Intestinal 
Table 1. Effect of nutritional status and rotavirus infection on body and small intestinal wt, serum albumin, and hematocrit*

\begin{tabular}{|c|c|c|c|c|}
\hline \multirow[b]{2}{*}{ Measured parameter } & \multicolumn{2}{|c|}{ Uninfected } & \multicolumn{2}{|c|}{ Rotavirus infected } \\
\hline & Malnourished $(n)$ & Control $(n)$ & Malnourished $(n)$ & Control $(n)$ \\
\hline Body wt (g) & $3.67 \pm 0.60(75) \dagger$ & $5.78 \pm 1.25(68)$ & $3.44 \pm 0.96(71) \ddagger$ & $5.37 \pm 0.85(74)$ \\
\hline Intestinal wt (g) & $0.18 \pm 0.04(66) \dagger$ & $0.25 \pm 0.08(68) \S$ & $0.18 \pm 0.05(58) \ddagger$ & $0.30 \pm 0.06(74)$ \\
\hline Albumin $(\mathrm{g} / 100 \mathrm{~mL})$ & $1.68 \pm 0.03(7) \dagger$ & $2.20 \pm 0.25(15)$ & $\mathrm{ND} \|$ & ND \\
\hline Hematocrit (\%) & $39 \pm 1.10(6)$ & $38.7 \pm 0.88(8)$ & $41.2 \pm 2.3(6)$ & $39.7 \pm 0.8(8)$ \\
\hline
\end{tabular}

$*$ Values are mean \pm S.D.

$\dagger p<0.001$ compared to uninfected normally nourished controls.

$\ddagger p<0.001$ compared to rotavirus infected normally nourished controls.

$\S p<0.001$ compared to rotavirus infected controls.

\| Not done.
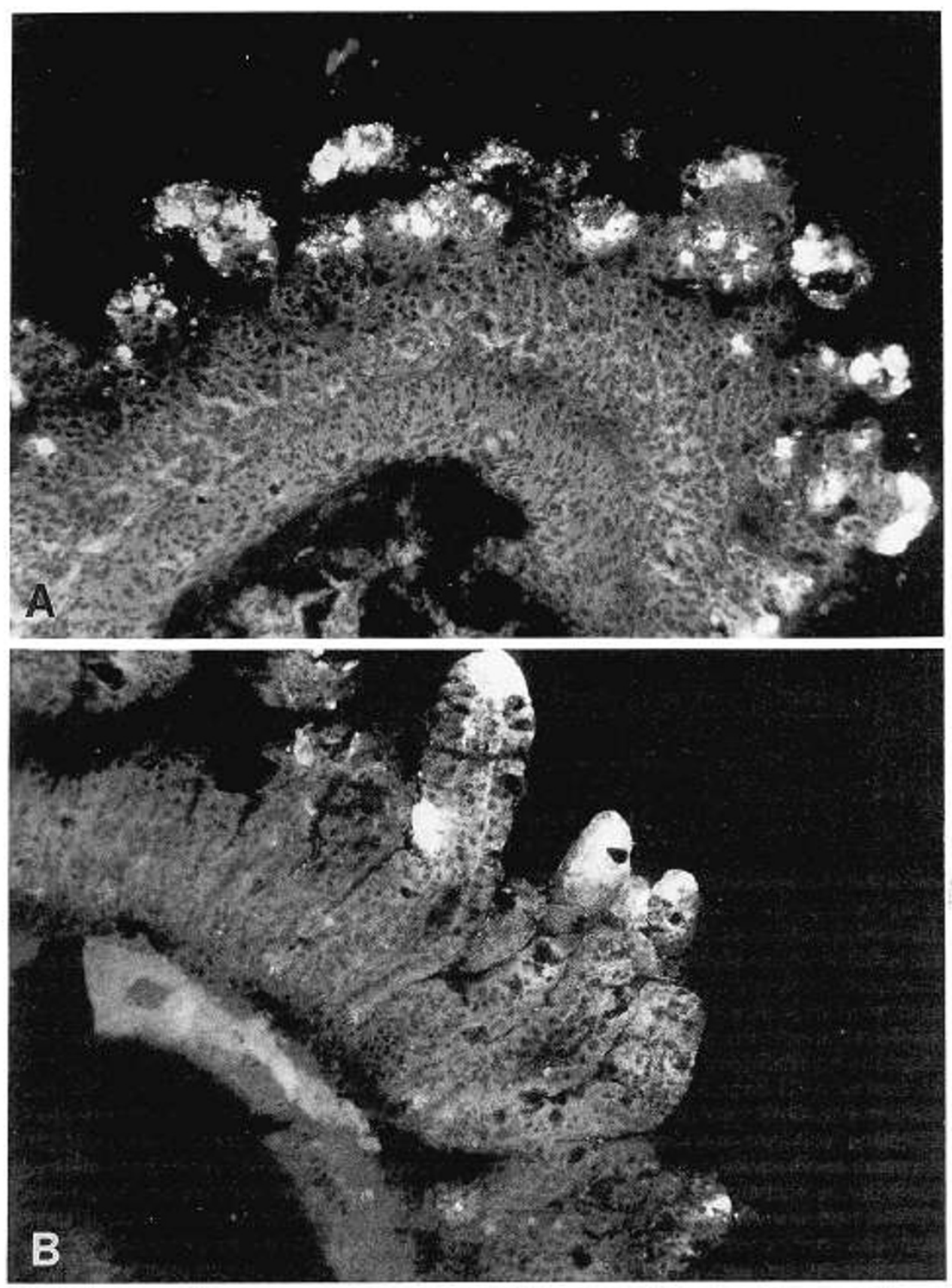

Fig. 1. Frozen sections of ileum, stained with guinea pig antirotavirus serum followed by fluorescein-conjugated anti-guinea pig IgG, from a 9d-old malnourished $(A)$ and a control $(B)$ mouse $3 \mathrm{~d}$ after oral inoculation with mouse rotavirus. 
sections from uninfected animals were negative for rotavirus antigen.

Intestinal morphology was evaluated in relation to malnutrition and rotavirus infection. Pathologic changes, when present, did not appear to have a predilection for a particular segment of the small bowel. Hematoxylin and eosin stained sections of small intestine from controls demonstrated a picture of tall and slender villi with a normal villus to crypt ratio of 5:1 (20) (Fig. $2 A$ ). In comparison, intestinal sections from malnourished mice revealed a mucosal pattern of variable atrophy, with stunted villi with
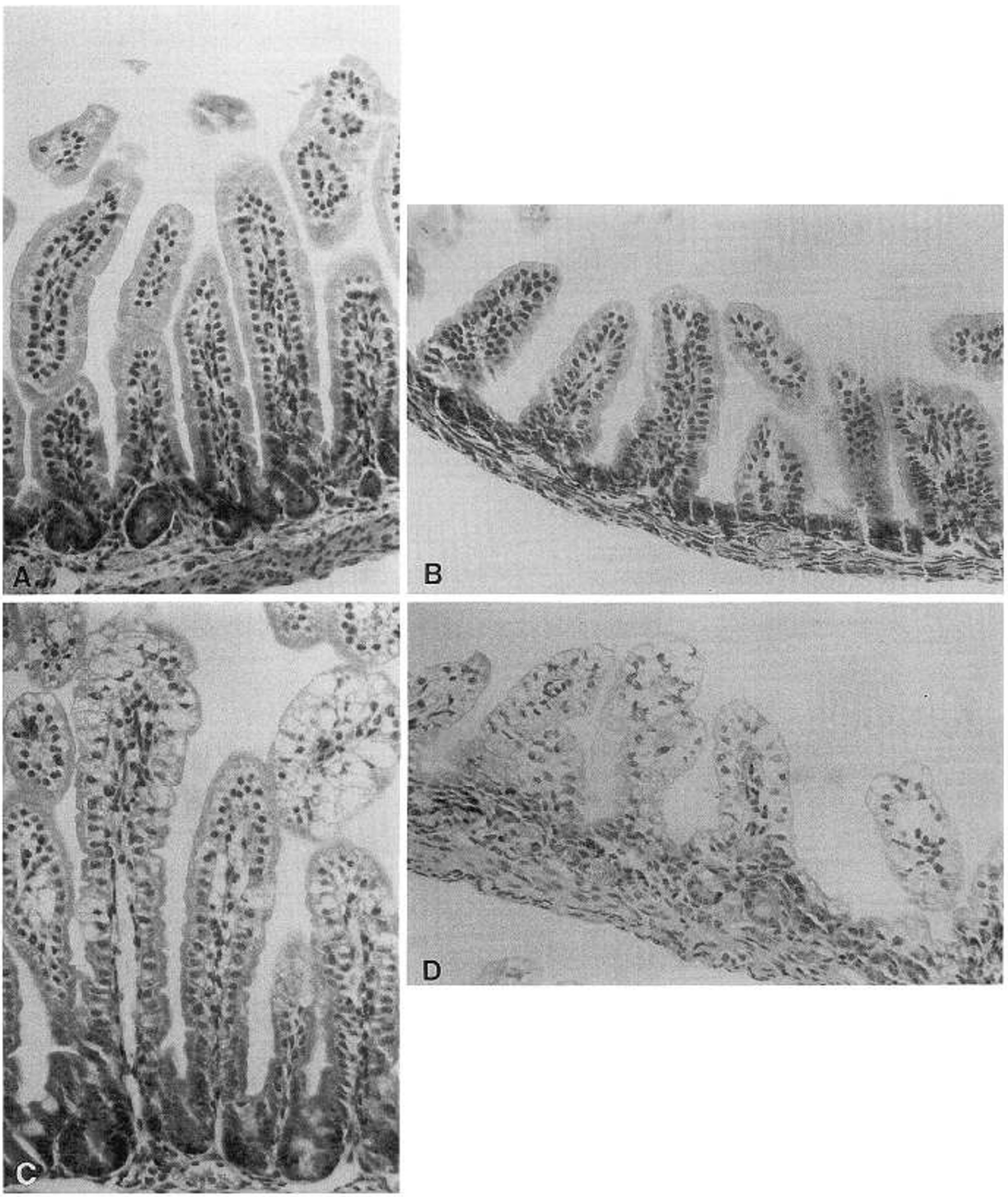

Fig. 2. Hematoxylin and eosin stained sections $(\times 400)$ of jejunum from 9-d-old mice: uninfected control $(A)$; uninfected malnourished $(B)$; rotavirus infected control $(C)$; and rotavirus infected malnourished $(D)$. 
diminished villus to crypt ratio of $2: 1$ between villi of normal ht (Fig. $2 B$ ). Rotavirus infection resulted in marked vacuolization of enterocytes on the tips of the villi giving them a honey-combed appearance (Fig. $2 C$ ). Mitotic figures were prominent in the crypts. In addition to rotavirus-induced morphologic changes,
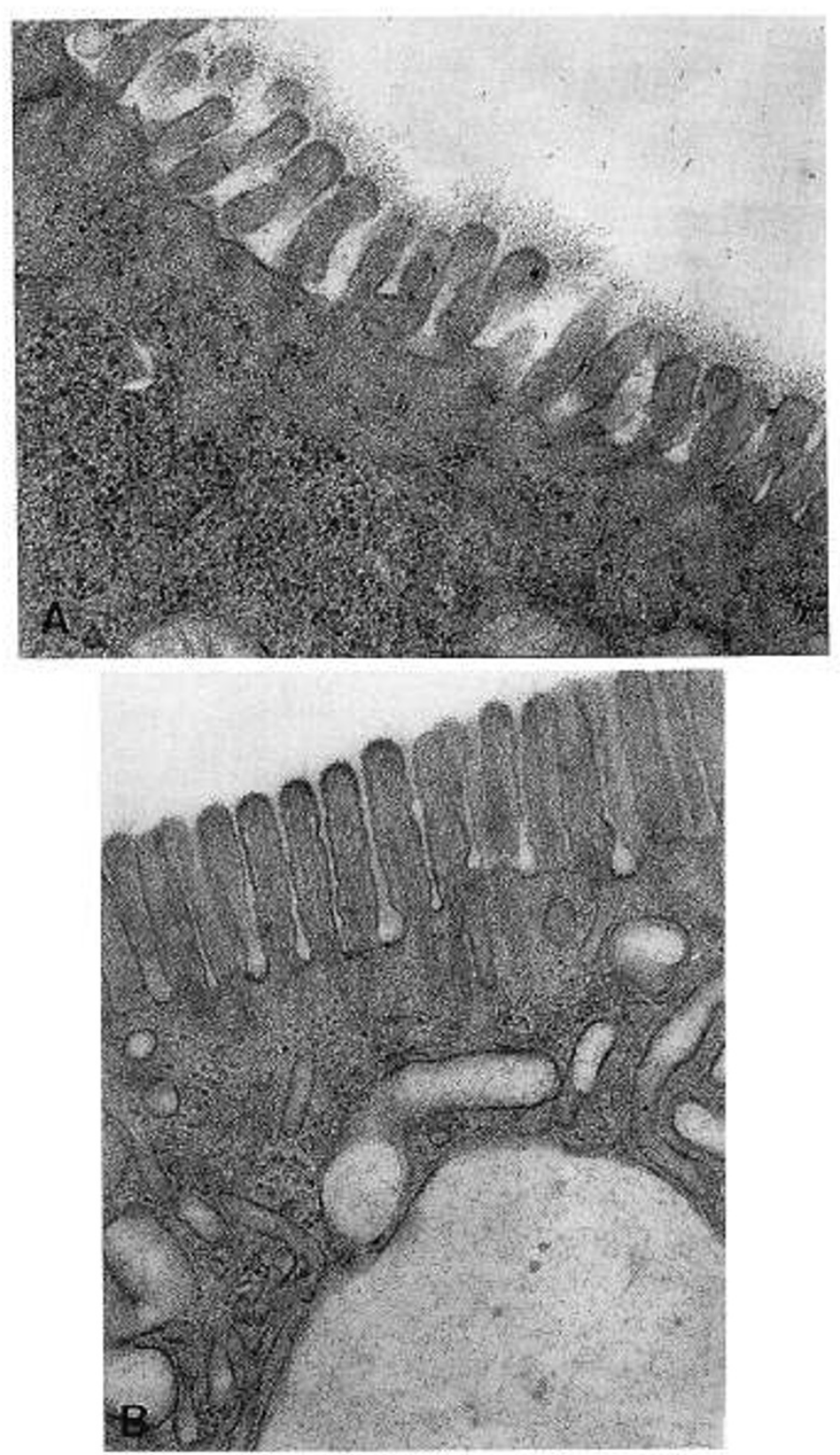

Fig. 3. Electron micrographs of lead citrate and uranyl acetate stained jejunal sections of microvillus border from a malnourished $(A)$ and control $(B)$ mouse $3 \mathrm{~d}$ after oral inoculation with mouse rotavirus $(\times 90$ $000)$. intestine from malnourished infected animals showed a pronounced diffuse mucosal atrophy with villi greatly reduced in ht (villus to crypt ratio of 2:1) and in numbers (Fig. $2 D$ ). The brush border was only present focally and was generally not identified, whereas in all other experimental groups the microvillus border was intact. These findings were confirmed by electron microscopy studies that revealed sparseness, shortening, irregular implantation, and branching of microvilli in the malnourished infected mice (Fig. $3 A$ ) as compared to a normal brush border (Fig. $3 B$ ) in the other animal groups. In rotavirus infected animals the vacuoles described at the light microscopy level occurred in the cytoplasmic matrix and seemed to be "empty." In malnourished infected animals, rotavirus particles were identified in scant quantities; however, no virus particles were detected in well-nourished infected controls.

Effect of nutrition and infection on uptake of OVA. OVA concentrations were determined in serum samples collected at intervals after intragastric feeding of $100 \mu \mathrm{g}$ of OVA to groups of rotavirus infected and uninfected normally nourished pups. Rotavirus infected animals attained significantly higher serum concentrations compared to uninfected mice at each sampling interval (data not shown). However, the intragastric feeding procedure was not adaptable to malnourished animals and was abandoned in favor of oral administration, the more natural route of exposure to dietary antigens. After oral administration, OVA concentrations in serum, gastric content, intestinal lavage fluid, and intestinal tissue homogenates were followed for $12 \mathrm{~h}$. To examine the temporal kinetics of OVA uptake more clearly during the first $3 \mathrm{~h}$, OVA levels were determined at frequent intervals during this time period, and thereafter with longer intervals.

The concentration of OVA in the gastric content rose to a pronounced peak at $5 \mathrm{~min}$ in all animal groups and thereafter declined gradually. In intestinal lavage fluid, OVA levels peaked at 45 to $60 \mathrm{~min}$ and were consistently higher in malnourished animals than well nourished controls throughout the observation period. The intestinal tissue concentrations of OVA per g intestine wt were significantly higher in malnourished animals as compared to controls (Table 2). Rotavirus infection resulted in lower intestinal concentrations of OVA both in well-nourished and protein-deficient animals.

Serum concentrations of OVA in the four experimental animal groups during the 12 -h observation period are illustrated in Figures 4 and 5 . The feeding of OVA by the oral route to wellnourished animals resulted in generally lower serum levels than the administration of antigen by the intragastric route to the same groups of mice. However, the serum OVA levels were still found to be consistently higher in rotavirus infected animals, both in normally nourished and malnourished mice. The high concentration of OVA in the sera at $5 \mathrm{~min}$ was attained rapidly in infected groups of animals. It should be pointed out that malnutrition alone also resulted in significantly increased uptake and serum concentrations of OVA compared to well-nourished uninfected (Fig. 4) and rotavirus infected (Fig. 5) controls. Interestingly, nutrient-deficient animals displayed a more prolonged height and slower decline of OVA concentration in sera.

Table 2. Intestinal tissue concentration of OVA $(\mu \mathrm{g} / \mathrm{mL})$ per $\mathrm{g}$ intestinal wt (mean $\pm S E M)$ in rotavirus-infected and uninfected mice in relation to nutritional status

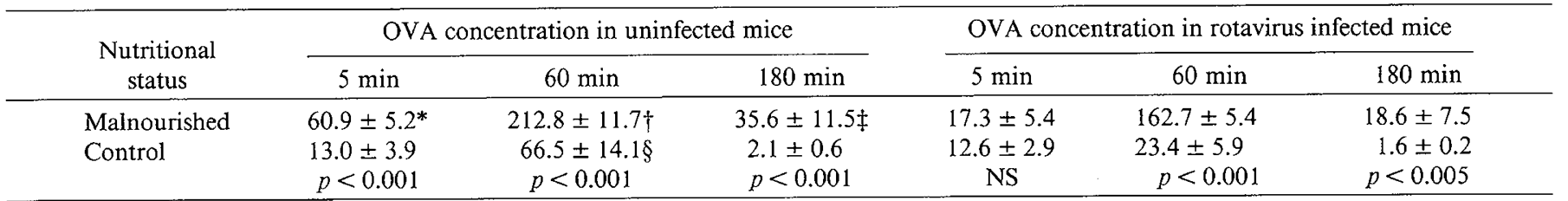

$* p<0.001$

$+p<0.005$.

$\ddagger p<0.01$ compared to malnourished rotavirus-infected animals.

$\S p<0.001$ compared to rotavirus-infected controls. $p$ values in Table 2 represent comparison between malnourished animals and controls. 


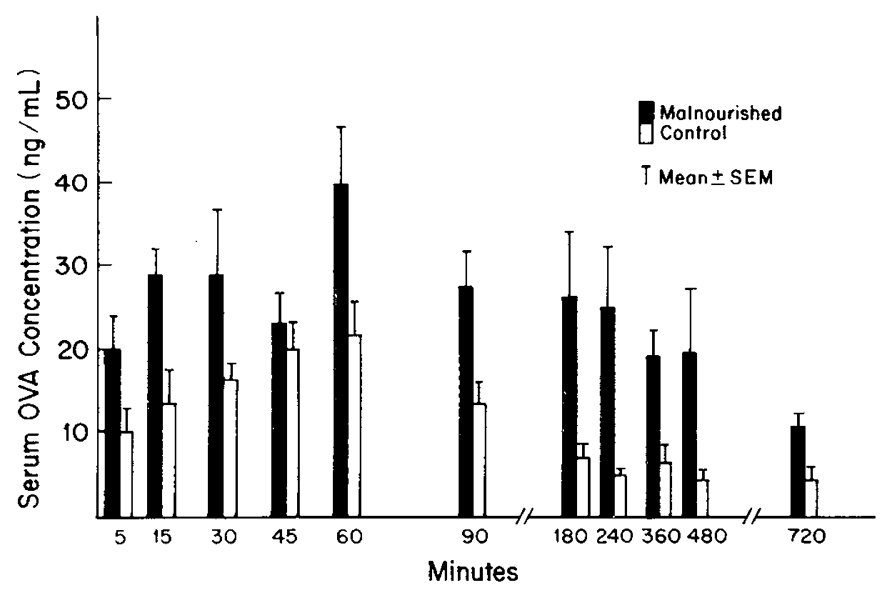

Fig. 4. Concentration of OVA $(\mathrm{ng} / \mathrm{mL})$ in serum of uninfected malnourished and control mice at different time intervals after oral administration of $100 \mu \mathrm{g}$ OVA.

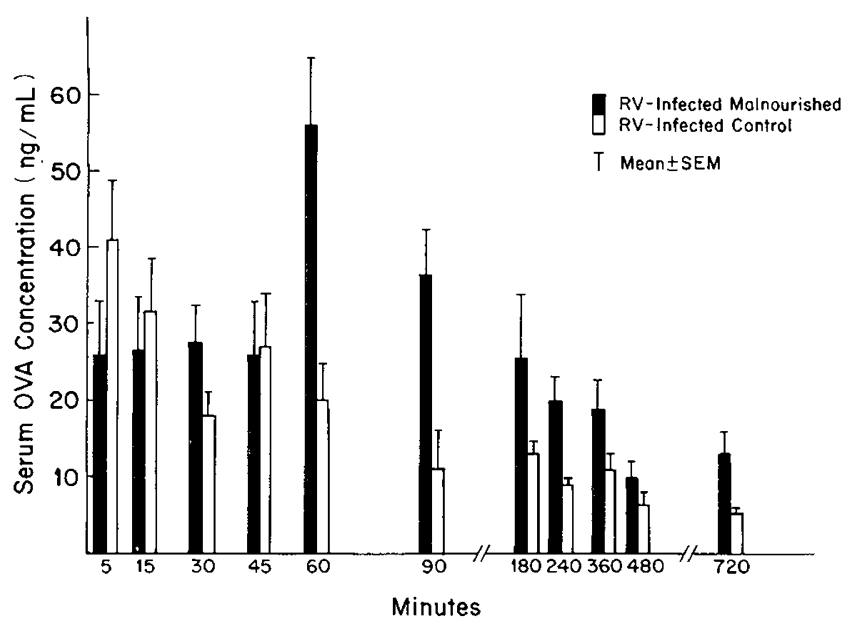

Fig. 5. Concentration of OVA $(\mathrm{ng} / \mathrm{mL})$ in serum of rotavirus $(R V)$ infected malnourished and control mice at different time intervals after oral administration of $100 \mu \mathrm{g}$ OVA.

When the amount of OVA transported at the peak level at 45 to $60 \mathrm{~min}$ was expressed per $\mathrm{g}$ body wt (data not shown) to control for the difference in size between malnourished and well nourished animals, the former showed approximately 2.5 times the uptake as the latter group. In rotavirus-infected animals, the uptake per g body wt was increased 4.5 times in malnourished mice compared to controls.

Because of large individual variations in OVA concentrations between animals, two-way analysis of variance was used. Comparison of multiple means of effect of time and group between malnourished and well-nourished animals showed that the change of serum OVA concentration with the time $(\mathrm{F}<6.39 p$ $<0.01)$ and especially with the group $(\mathrm{F}<7.26, p<0.0001)$ was significantly different.

\section{DISCUSSION}

Our data suggest that both malnutrition and acute infection with rotavirus result in increased intestinal absorption of dietary macromolecules. The effects were most pronounced in malnourished infected animals. Significantly, however, malnutrition alone also resulted in higher serum and intestinal tissue levels of OVA, suggesting that under conditions of protein-calorie deficiency, the intestine may become more permeable to the absorp- tion of dietary and other environmental antigens. Similar data from other animal models and observations in children corroborate these findings. It has been shown that young rats exposed to prolonged protein deficiency $(21-23)$, as well as newborn rabbits exposed to short-term starvation (24), exhibit enhanced intestinal absorption of bovine serum albumin. Recently, Heyman et al. (25) reported increased uptake of horseradish peroxidase in jejunal biopsies from children during malnutrition, which was reversed after 3 mo of nutritional rehabilitation. The mechanisms underlying these alterations in intestinal barrier function are not well understood. It is known that malnutrition produces atrophy of small intestinal mucosa in experimental animals (21, 26 ), including the murine model as shown in this study, as well as in humans $(8,25)$. The role of mucosal damage in the uptake of antigens has been investigated in a number of experimental models. Studies with surgical trauma (27), prolonged feeding of disaccharidases (28), or deconjugated bile salts (29) and chronicsevere malnutrition (25) have suggested several mechanisms, including alterations in epithelial barriers, tight junctions, and endocyticlysomal processes that could account for an enhancement in intestinal transport of macromolecules. As for malnutrition, it has been demonstrated that protein-deficient rats exhibit an increase in pinocytic activity and a deterioration of apical junctions with movement of protein molecules directly between cells (21). In support of these observations, we found a marked augmentation of OVA concentrations in intestinal tissue of malnourished animals, which clearly indicates that more antigen is transported across the gut epithelium and is accumulated in the intestinal tissue during malnutrition. Other influential factors that might operate in the protein-deficient host to increase the antigen uptake include local secretory antibody deficiency in the gut, reduced gastric acidity and pancreatic enzyme activity, and delay in postnatal maturation of the small intestinal epithelium (9).

Earlier studies by Gruskay and Cooke (30), carried out over $35 \mathrm{y}$ ago, provided evidence of an increased uptake of egg albumin in infants recovering from gastrointestinal infection with diarrhea, compared to control children. In other previous investigations it has been found that children with diarrhea have a higher occurrence of mucosal antibodies against bacterial antigens (31), an increase of jejunal mucosal cells containing IgA (32), and higher levels of fecal $\alpha$-1-antitrypsin (33). Recent studies in humans have provided more direct evidence that intact molecules cross an infected gut mucosa to a greater extent than a normal intestine (34). Lately, attempts have been made in animal models to document whether specific enteropathogens have different effects on the gut mucosal transport of antigens. Secretory diarrhea, induced with cholera toxin in ligated loops of rabbit jejunum has not been found to be associated with increased intact protein absorption (35). In contrast, transmissible gastroenteritis virus in piglets (36), which is accompanied by mucosal damage, has been shown to cause a marked augmentation in intestinal uptake of macromolecules. Our studies with rotavirus, a strict enteric pathogen that selectively infects and replicates in the mature villi enterocytes, leading to extrusion of cells and mucosal damage, support these observations. At the peak of rotavirus diarrhea, an increased absorption of OVA was demonstrated in infected animals compared to controls. Similarly, Heyman et al. (37), who measured transport of horseradish peroxidase in vitro in segments of mouse jejunum during and immediately after rotavirus infection, found a 5-fold rise in protein absorption during the diarrheal period (d 2 and 3 pi). The peak of rotavirus diarrhea also coincides with a peak in thymidine kinase activity (38), a marker of crypt cell proliferation, which in turn is correlated to changes in tight junction of crypt cells (39), suggesting that the leakiness of the epithelium might be increased during this stage of disease.

The enhancement of antigen uptake during acute viral infection has also been documented in the respiratory tract. In related 
studies in our laboratory, it was found that the uptake of intranasally administered OVA was significantly increased during infection with respiratory syncytial virus (40). The mechanisms underlying these alterations in mucosal barrier function are not known. Several possible explanations may exist including the development of mucosal damage during acute viral infection, the induction of specific absorptive mechanisms such as receptormediated pinocytosis, and alterations in antigen processing as a result of the infectious process. Recently, the importance of another factor, the mucosal microflora, was demonstrated in a study of intestinal absorption of macromolecules during rotavirus infection in conventional and germ-free mice (37).

Finally, the most striking effect on the absorption of OVA in mouse intestine was provided by the combination of malnutrition and rotavirus infection. The uptake of OVA was found to be increased 4.5 times in association with malnutrition and infection, whereas malnourished uninfected animals exhibited twice the uptake of normally nourished controls. In addition, the combination of rotavirus infection and protein deficiency appeared to intensify the mucosal atrophy and disruption of microvilli. These data suggest a synergistic effect of nutritional depletion and infection on intestinal transport mechanisms, as well as on the extent of mucosal damage. One possible explanation for the increased virulence of enteric pathogens in malnutrition might be a loss of intestinal barrier function with direct penetration of intestinal organisms and toxins into systemic circulation. In fact, Worthington and Syrotuck (41) have reported breakdown of junctional complexes and presence of intercellular tracer materials (adenovirus particles) in the epithelium and lamina propria of intestinal mucosa of protein-deficient rats but not in controls.

Evidence is accumulating that clearly suggests that macromolecular absorption may result in pathophysiologic changes in man (12). Diseases believed to be associated with alterations in intestinal mucosal barrier function include inflammatory bowel disease, gastrointestinal allergy, celiac disease, toxigenic diarrheas, and autoimmune diseases (12). The increased uptake of macromolecules may underlie the broadbased immunologic alterations to food antigens observed during enteric viral infection and malnutrition $(13,42)$. In fact, it has been demonstrated that dietary proteins administered in the airway during viral infection resulted in a significantly altered immune response $(40)$. Viral enteritis in early infancy might be one of the causes of sensitization to food antigens leading to allergic manifestations (42). This raises the important question of feeding during diarrhea because adverse nutritional effects must be avoided but, on the other hand, resumption of feeding in the early phase of diarrhea has been shown to be beneficial in shortening the duration of diarrhea and promoting a rapid wt gain. The increased uptake of food antigens in protein-calorie malnutrition may have an important effect on the immune system and therefore play a role in the immunopathology of malnutrition. At present, it is not known if an increased passage of antigenic material into the systemic circulation during malnutrition and viral enteritis involves harmful stimulation of the immunologic system. A greater understanding of the nature of allergens, the antigen handling in the gut, and the response of IgE antibody to macromolecule transport in the small intestines is necessary before the pathogenesis of gastrointestinal allergy and other related diseases can be clearly understood.

\section{REFERENCES}

1. Chen LC 1983 Interactions of diarrhea and malnutrition. In: Chen LC Scrimshaw NS (eds) Diarrhea and Malnutrition. Plenum Press, New York, pp 3-19

2. Cukor G, Blacklow NR 1984 Human viral gastroenteritis. Microbiol Rev 48:157-159

3. Black RE, Merson MH, Rahman ASMM, Yunus M, Alim ARMA, Huq I, Yolken RH, Curlin GT 1980 A two-year study of bacterial, viral and parasitic agents associated with diarrhea in rural Bangladesh. J Infect Dis 142:660-
664

4. Gordon JE, Guzman MA, Ascoli W, Scrimshaw NS 1964 Acute diarrhoeal disease in less developed countries. 2. Patterns of epidemiological behaviour in rural Guatemalan villages. Bull WHO 31:9-20

5. Black RE, Brown $\mathrm{KH}$, Becker $\mathrm{S} 1984$ Malnutrition is a determining factor in diarrheal duration, but not incidence, among young children in a longitudinal study in rural Bangladesh. Am J Clin Nutr 37:87-94

6. Davidson GP, Barnes GL 1979 Structural and functional abnormalities of the small intestine in infants and young children with rotavirus enteritis. Acta Paediatr Scand 68:181-186

7. Coelho KIR, Bryden AS, Hall C, Flewett TH 1981 Animal model. Pathology of rotavirus infection in suckling mice: a study by conventional histology, immunofluorescence, ultrathin sections and scanning electron microscopy. Ultrastruct Pathol 2:59-80

8. Brunser O, Reid A, Mockeberg F, Maccioni A, Contreras I 1968 Jejunal mucosa in infant malnutrition. Am J Clin Nutr 21:976-983

9. Viteri FE, Schneider RE 1974 Gastrointestinal alterations in protein-calorie malnutrition. Med Clin North Am 58:1487-1505

10. Sirisinha S, Suskind R, Edelman R, Asvapaka C, Olson RE 1975 Secretory and serum IgA in children with protein-calorie malnutrition. Pediatrics $55: 166-170$

11. Reddy V, Raghuramulu N, Bhaskaram C 1976 Secretory IgA in protein-calorie malnutrition. Arch Dis Child 51:871-874

12. Walker WA, Isselbacher KJ 1974 Uptake and transport of macromolecules by the intestine. Possible role in clinical disorders. Gastroenterology 67:531550

13. Chandra RK 1975 Food antibodies in malnutrition. Arch Dis Child 50:532-

14. Riepenhoff-Talty M, Suzuki H, Ogra PL 1983 Etiologic agents of acute diarrhea. Selected aspects of pathogenesis of human and murine rotavirus infection. In: Bellanti JA (ed) Acute Diarrhea: Its Nutritional Consequences in Children. Nestle' Nutrition Workshop Series, Vol 2. Raven Press, New York, pp 43-49

15. Winick M, Noble A 1966 Cellular response in rats during malnutrition at various ages. J Nutr 89:300-306

16. Offor E, Riepenhoff-Talty M, Ogra PL 1985 Effect of malnutrition on rotavirus infection in suckling mice: kinetics of early infection. Proc Soc Exp Biol Med 178:85-90

17. Reed LJ, Muench $\mathrm{H} 1938$ A simple method of estimating fifty percent endpoints. Am J Hygiene 27:493-497

18. Edevag G, Eriksson M, Granstrom M 1986 The development and standardization of an ELISA for ovalbumin determination in influenza vaccines. $J$ Biol Stand 14:223-230

19. Riepenhoff-Talty M, Dharakul T, Kowalski E, Sterman D, Ogra PL 1987 Rotavirus infection in mice: pathogenesis and immunity. In: Mestecky J, McGhee JR, Bienenstock J, Ogra PL (eds) Recent Advances in Mucosal Immunology, Part B, Plenum Publishing Co, New York, pp 1015-1023

20. Herbst JJ, Sunshine P 1969 Postnatal development of the small intestine of the rat. Pediatr Res 3:27-33

21. Worthington BS, Boatman ES, Kenny GE 1974 Intestinal absorption of intact proteins in normal and protein-deficient rats. Am $J$ Clin Nutr 27:276-286

22. Rothman D, Latham MC, Walker WA 1982 Transport of macromolecules in malnourished animals. I. Evidence for increased uptake of intestinal antigens. Nutr Res 3:467-473

23. Rothman D, Latham MC, Walker WA 1982 Transport of macromolecules in malnourished animals. II. Intravenous clearance after antigen absorption. Nutr Res 2:475-480

24. Rothman D, Udall JN, Pang KY, Kirkham SE, Walker WA 1985 The effect of short-term starvation on mucosal barrier function in the newborn rabbit. Pediatr Res 19:727-731

25. Heyman M, Boudraa G, Sarrut S, Giraud M, Evans L, Touhami M, Desjeux JF 1984 Macromolecular transport in jejunal mucosa of children with severe malnutrition: a quantitative study. J Pediatr Gastroenterol Nutr 3:357-363

26. Butzner JD, Gall DG 1988 Effects of chronic protein-calorie malnutrition on small intestinal repair after an acute bacterial enteritis: a study in infant rabbits. Pediatr Res 23:408-413

27. Rhodes RS, Karnovsky JM 1971 Loss of macromolecular barrier function associated with surgical trauma to the intestine. Lab Invest 25:220-229

28. Teichberg S, Lifshitz F, Pergolizzi R, Wapnir RA 1978 Response of rat intestine to a hyperosmotic feeding. Pediatr Res 12:720-725

29. Fagundes-Neto U, Teichberg S, Bayne MA, Morton B, Lifshitz F 1981 Bile salt-enhanced rat jejunal absorption of a macromolecular tracer. Lab Invest 44:18-26

30. Gruskay FL, Cooke RE 1955 The gastrointestinal absorption of unaltered protein in normal infants and in infants recovering from diarrhea. Pediatrics 16:763-769

31. Avigad S, Manuel P, Bampoe V, Walker-Smith JA, Shiner M 1978 Smallintestinal mucosal antibodies against antigens of non-pathogenic luminal or mucosal bacteria in young children with and without diarrhoea. Lancet $1: 1130-1132$

32. Green F, Heyworth B 1980 Immunoglobulin-containing cells in jejunal mucosa of children with protein-energy malnutrition and gastroenteritis. Arch Dis Child 55:380-383

33. Maki M, Harmoinen A, Vesikari T, Visakorpi JK 1982 Faecal excretion of alpha-1-antitrypsin in acute diarrhoea. Arch Dis Child 57:154-156

34. Ford RPK, Menzies IS, Phillips AD, Walker-Smith JA, Turner MW 1985 
Intestinal sugar permeability: relationship to diarrhoeal disease and small bowel morphology. J Ped Gastroenterol Nutr 4:568-574

35. Heyman M, Dumontier AM, Desjeux JF 1985 Intestinal barrier to intact horseradish peroxidase in experimental secretory diarrhea. J Pediatr Gastroenterol Nutr 5:463-466

36. Keljo DJ, Butler DG, Hamilton RJ 1985 Altered jejunal permeability to macromolecules during vital enteritis in the piglet. Gastroenterology 88:998 1004

37. Heyman M, Corthier G, Petit A, Meslin JC, Moreau C, Desjeux JF 1987 Intestinal absorption of macromolecules during viral enteritis: an experimental study on rotavirus-infected conventional and germ-free mice. Pediatr Res 22:72-78

38. Collins J, Starkey WG, Wallis TS, Clarke GJ, Worton KJ, Spencer AJ, Haddon
SJ, Osborne MP, Candy DCA, Stephen J 1988 Intestinal enzyme profiles in normal and rotavirus-infected mice. J Pediatr Gastroenterol Nutr 7:264-272 39. Tice LW, Carter RL, Cahill MB 1979 Changes in tight junctions of rat intestinal crypt cells associated with changes in their mitotic activity. Tissue Cell 11:293-316

40. Freihorst J, Piedra PA, Okamoto Y, Ogra PL 1988 Effect of respiratory syncytial virus infection on the uptake of and immune response to other inhaled antigens. Proc Soc Exp Biol Med 188:191-197

41. Worthington BS, Syrotuck J 1976 Intestinal permeability to large particles in normal and protein-deficient adult rats. J Nutr 106:20-32

42. Ogra PL, Welliver RC, Riepenhoff-Talty M, Faden HS 1984 Interaction of mucosal immune systems and infections in infancy: implications in allergy. Ann Allergy 53:523-534 